\title{
Use of the vacuum extractor in the community hospital
}

\author{
JOSEPH A. FOGARTY, JR, DO
}

\begin{abstract}
As obstetrical technique
continues to develop, newer forms of instrumental delivery have developed. This article reviews 255 deliveries over a sixyear period. These cases were taken from private and clinic practice in a general hospital setting. Both Kobayashi and Mityvac extractors were used with and without anesthesia. The use of the malleable extractor has proven a safe and versatile addition to the armamentarium of the obstetrician.
\end{abstract}

By the mid $1960 \mathrm{~s}$, the development of both operative obstetrics and obstetrical anesthesia established the combination of low-forceps deliveries under conduction anesthesia in a great number of community hospitals. While such methods were not routine, they represented a standard to be met. The use of conduction anesthesia is dependent upon the availability of personnel with specific skills; this criterion usually is outside the control of the accoucheur. The operative forceps are totally under the obstetrician's control, however.

Four elements of risk are inherent in the use of obstetric forceps: First, the introduction of the blade into a vaginal vault already occupied by an infant's head risks laceration of the lateral walls. Intravaginal manipulation, such as rotation of the head, increases this risk. Second, the application of the forceps against the infant's parietal and facial areas produces compression of the head to the point of bruising or abrasion, fracture, or even intracranial hemorrhage. While rare, these events are catastrophic.

Third, even proper application of the forceps increases the mass passing through the introitus. Despite an adequate episiotomy, this increase can produce forces exceeding the inherent tone of the perineal musculature, which results in lacerations. Such events are more common with local infiltration or when anesthesia is not used. Fourth, the forceps used in low techniques are designed to overcome resistance of the soft tissue. Injudicious or overenthusiastic traction on the forceps may cause injuries to mother or infant. While the state of the instruments remained static, the traditional means of reducing these risks lay solely in the maximization of the obstetrician's skills.

An alternative approach was offered in the early $1950 \mathrm{~s}$ in the form of the Malmström vacuum extractor, which was based on a concept introduced in 1706 by Yonge. ${ }^{1} \mathrm{~A}$ shaped metal cup was applied to the infant's head, negative pressure was applied inside the cup, and a caput succedaneum was created, which allowed traction and rotational forces to be used to augment the mother's expulsive efforts. This instrument was smaller in diameter than the infant's head and produced minimal lateral compression. Thus, it reduced the risk of lateral wall laceration, episiotomy extension, and intracerebral injury. In the hands of such skilled obstetricians as Eisenberg, ${ }^{1}$ these benefits were, indeed, obtained.

Deficiencies inherent in the Malmström unit did cause problems. The rigidity and the shape of the cup resulted in excessive caput succedaneum formation. The negative pressure on the rigid edge of the cup produced scratches, skin dehiscence, and subcutaneous hemorrhage. ${ }^{2,3}$ Fortunately, once the basic technique proved effective, improvements in equipment followed.

In the $1970 \mathrm{~s}$, semimaleable materials and changes in the shape of the cephalic portion of the cup were introduced in the form of the Kobayashi and Mityvac instruments. ${ }^{4}$ Considerable benefits are seen when comparing these new units to both obstetric forceps and the Malmström extractor. The softer material of the cup allows easier transvaginal application. Also, the gentle cone shape decreases the severity of the caput succedaneum ${ }^{5}$; the Kobayashi unit is more effective in this aspect. In addition, excessive perineal resistance causes suction to be lost, so the instrument pops off before damage to the infant occurs. And, finally, the newer instruments can be used with conduction or local anesthesia, or without any anesthesia.

However, there are problems in using the newer vacuum extractors. First, rotation of the presenting head is possible but more difficult than it is when using forceps. Second, the instrument primarily is used to augment forces of the mother and is limited in its ability to overcome resistance by a thick, firm perineum. Third, inadvertent trapping of the cervix or vaginal mucosa between the 
suction cup edge and the infant's head can produce hematomas or skin dehiscence.

I have found the Mityvac unit to be less advantageous because of the less comfortable grip and the more pronounced caput succedaneum. It is, however, a smaller unit, which affords greater ease of insertion and less risk of trapping of the mucosa.

\section{Materials and methods}

The 253 patients included in this report were taken from my private and clinic practices from Dec 1981 through Nov 1987. Of these, $98 \%$ were delivered by myself or under my direct supervision. Conduction anesthesia was provided through the hospital department of anesthesia, while local anesthesia was administered by myself or an assistant. Apgar ratings were estimated by anesthesiologists, delivery room nurses, or myself.

During the period of the report, both interns and medical students were instructed successfully in the use of the vacuum extractor.

Criteria for application of the extractor were complete dilation, descent of the biparietal diameter to $+1 /+2$ station, rupture of the membranes; and optional episiotomy.

As expertise increased, it was found that this instrument could be applied with or without anesthesia, that rotations could be performed from the posterior or transverse positions, that both the first and second of twins could be delivered in this way, and that premature infants did not tolerate the procedure well, even at reduced negative pressures. While multiparous women tolerated the technique very well, primiparous patients experienced more problems from the inherently firm perineal tone. Extension of the episiotomy did occur in some cases, but less frequently than with forceps use.

The 253 patients ranged in age from 14 to 41 years (average, 25.1 years). There were 90 primiparas (35.6\%) and 163 multiparas (64.4\%). Gestational ages ranged from 24 to 43 weeks (average, 39.7 weeks). Birth weights ranged from $2 \mathrm{lb}$ $14 \mathrm{oz}(1,304 \mathrm{~g})$ to $14 \mathrm{lb} 12 \mathrm{oz}(5,854 \mathrm{~g})$.

Anesthesia was administered in 246 cases (97.2\%); 188 patients had epidural block and 58 patients had local anesthesia.

Complications of delivery included extension of the episiotomy, depression of the infant, and failure of the technique.

Episiotomy was performed for 232 patients $(92 \%)$. There was fourth-degree extension of the midline episiotomy in 29 patients $(12.5 \%) ; 22$ of these patients were primiparous and 7 were multiparous.

Condition of the 255 neonates was evaluated by the one-minute and five-minute Apgar scores. Apgar scores of 7 or less were used to denote depression. There were 17 infants $(6.7 \%)$ with oneminute Apgar scores below 7 (Table 1). Only three showed depression that possibly was associated with technique. Five infants (2.0) had Apgar scores of 7 or less at five minutes. Only one infant might have been depressed because of the procedure. Table 2 lists the various causes of infant depression. One infant death occurred in utero from unknown causes.

Failure of the vacuum extractor technique occurred in 12 patients $(4.7 \%)$ (Table 3 ). Eight of these failures were in primipara and four in multipara. Laufe-Piper forceps were used to deliver 11 of these infants; cesarean section was necessary in one case. Rotation with Barton forceps was necessary for two neonates, whose birth weights each exceeded previous siblings by approximately $2 \mathrm{lb}$. Four infants presented in a persistent occiput posterior position, while four exceeded $3,800 \mathrm{~g}$ in birth weight.

\section{Summary}

For the uncomplicated vaginal delivery, the ease

\begin{tabular}{|lccc|}
\hline \multicolumn{4}{|l|}{ TABLE 1. APGAR SCORES OF 255 INFANTS.* } \\
\hline $\begin{array}{l}\text { One-minute } \\
\text { score }\end{array}$ & $\begin{array}{l}\text { Numbers of } \\
\text { infants (\%) }\end{array}$ & $\begin{array}{c}\text { Five-minute } \\
\text { score }\end{array}$ & $\begin{array}{r}\text { Numbers of } \\
\text { infants (\%) }\end{array}$ \\
\hline$<7$ & $17(6.7)$ & $<7$ & $5(2.0)$ \\
7,8 & $125(49.0)$ & 7,8 & $15(5.9)$ \\
9,10 & $113(44.3)$ & 9,10 & $235(92.1)$ \\
\hline *There were two cases of twin delivery. & & \\
\hline
\end{tabular}

\begin{tabular}{|c|c|c|c|}
\hline \multicolumn{2}{|c|}{ One-minute depression } & \multicolumn{2}{|c|}{ Five-minute depression } \\
\hline No. & Cause & No. & Cause \\
\hline 6 & $\begin{array}{l}\text { Circumnuchal cord } \\
\text { with compression }\end{array}$ & 1 & $\begin{array}{l}\text { Circumnuchal cord } \\
\text { with compression }\end{array}$ \\
\hline 1 & $\begin{array}{l}\text { Multiple congenital } \\
\text { anomalies }\end{array}$ & 1 & $\begin{array}{l}\text { Maternal drug addic- } \\
\text { tion, with intrapar- }\end{array}$ \\
\hline 1 & $\begin{array}{l}\text { Persistent occiput pos- } \\
\text { terior position, with } \\
\text { rotational and de- } \\
\text { livery difficulties } \\
\text { Predelivery fetal heart }\end{array}$ & & $\begin{array}{l}\text { tum fetal heart tone } \\
\text { depression; new- } \\
\text { born stillborn fail- } \\
\text { ing to respond to } \\
\text { treatment }\end{array}$ \\
\hline 4 & tone depression & 1 & Persistent occiput pos- \\
\hline 1 & Occult cord prolapse & & terior position, with \\
\hline 1 & $\begin{array}{l}\text { Maternal drug addic- } \\
\text { tion with intrapar- }\end{array}$ & & $\begin{array}{l}\text { rotational and de- } \\
\text { livery difficulties }\end{array}$ \\
\hline & $\begin{array}{l}\text { tum fetal heart tone } \\
\text { depression; new- } \\
\text { born died }\end{array}$ & 1 & $\begin{array}{l}\text { Unknown, possibly } \\
\text { technique related }\end{array}$ \\
\hline 3 & $\begin{array}{l}\text { Cause unknown, possi- } \\
\text { bly technique re- } \\
\text { lated }\end{array}$ & & \\
\hline
\end{tabular}




\begin{tabular}{|c|c|c|c|c|c|c|c|}
\hline \multirow[b]{2}{*}{ Parity } & \multirow{2}{*}{$\begin{array}{l}\text { Maternal } \\
\text { age }\end{array}$} & \multirow{2}{*}{$\begin{array}{c}\text { Gestational } \\
\text { age }\end{array}$} & \multirow[b]{2}{*}{ Anesthesia } & \multicolumn{2}{|c|}{ Apgar } & \multirow{2}{*}{$\begin{array}{c}\text { Birth } \\
\text { weight }(\mathrm{g})\end{array}$} & \multirow[b]{2}{*}{ Comment } \\
\hline & & & & $1 \mathrm{~min}$ & $5 \mathrm{~min}$ & & \\
\hline 00102 & 17 & 39 & Epidural & 8 & 10 & 3,529 & Large baby \\
\hline 00001 & 26 & 42 & Epidural & 8 & 10 & 3,636 & $\begin{array}{l}\text { POPP*; rotation re- } \\
\text { quired }\end{array}$ \\
\hline 00001 & 25 & 38 & Epidural & 6 & 8 & 4,171 & Huge infant \\
\hline 00001 & 19 & 40 & Local & 1 & 2 & 3,414 & $\begin{array}{l}\text { POPP; rotation re- } \\
\text { quired }\end{array}$ \\
\hline 10012 & 26 & 40 & Epidural & 9 & 10 & 3,829 & $\begin{array}{l}\text { POPP and failure to } \\
\text { descend; weight } \\
2 \text { lbs more than } \\
\text { sibling }\end{array}$ \\
\hline 10113 & 25 & 42 & Epidural & 8 & 10 & 3,371 & $\begin{array}{l}\text { Premature rupture } \\
\text { of membranes; } \\
\text { fetal distress }\end{array}$ \\
\hline 10012 & 24 & 42 & Epidural & 7 & 9 & 3,857 & $\begin{array}{l}\text { POPP; weight } 2 \mathrm{lbs} \\
\text { more than sib- } \\
\text { ling } \\
\text { Tight musculature }\end{array}$ \\
\hline 00001 & 18 & 42 & Epidural & 7 & 9 & 4,529 & $\begin{array}{l}\text { Huge infant; tight } \\
\text { musculature }\end{array}$ \\
\hline 00001 & 20 & 40 & Epidural & 7 & 9 & 3,536 & $\begin{array}{l}\text { Marked perineal } \\
\text { and soft-tissue } \\
\text { resistance }\end{array}$ \\
\hline 00001 & 20 & 40 & Epidural & 9 & 10 & 3,086 & POPP \\
\hline 00001 & 33 & 40 & Epidural & 7 & 10 & 4,043 & No reason \\
\hline 20124 & 36 & 40 & Epidural & 7 & 10 & 3,957 & $\begin{array}{l}\text { Deep transverse } \\
\text { arrest }\end{array}$ \\
\hline
\end{tabular}

and safety of application of the new Kobayashi and Mityvac vacuum extractor reduces the risks to well below those associated with low forceps use. Proper use of these instruments can be taught readily to graduate physicians and medical students.

The modern vacuum extractor is a safe, versatile, and effective instrument. It is suitable for use in the general hospital and by general practitioners with obstetric privileges.

1. Eisenberg $\mathrm{L}$ : Use of the vacuum extractor in obstetrical delivery: $\mathrm{Re}$ port of 600 cases. JAOA 1972;71:846-850.
2. Bird, GC: The use of vacuum extractor. Clin Obstet Gynecol 1982;9:641661

3. Plauche WC: Fetal cranial injuries related to delivery with the Malmström vacuum extractor. Obstet Gynecol 1979;53:751-757.

4. Chamberlain G: Forceps and vacuum extraction. Clin Obstet Gy. necol1980;7:511-527.

5. Maryniak GM, Frank JB: Clinical assessment of the Kobayashi vacuum extractor. Obstet Gynecol 1984;64:431-435.

From the Department of Obstetrics and Gynecology, Youngstown Osteopathic Hospital, Youngstown, Ohio.

Reprint requests to Dr Fogarty, 84 Broadway, Youngstown, $\mathrm{OH}$ 44505 . 